\title{
Benthic Foraminifera from Middle to Late Pleistocene, coastal upwelling sediments of ODP Hole 686B, Pacific Ocean, off Peru
}

\author{
KATHRYN A. MALMGREN ${ }^{1}$ and BRIAN M. FUNNELL ${ }^{2}$ \\ '(née YOUNG) Västertorp, Strömma, S-13900, Värmdo, Sweden \\ ${ }^{2}$ School of Environmental Sciences, University of East Anglia, Norwich NR4 7TJ
}

\begin{abstract}
Benthic Foraminifera from middle to late Pleistocene, (c. $600 \mathrm{ka}$ to $0 \mathrm{ka}$ ), sediments of ODP Hole 686B, off Peru, show highest abundances and diversities during periods of cooler surface waters, (inferred from the $U^{k}{ }_{37}$ index), and enhanced upwelling, (inferred from the peridinacean/gonyaulacacean dinoflagellate cyst ratio). During the latest Pleistocene, $(c .160 \mathrm{ka}$ to $0 \mathrm{ka}$ ), these periods are characterised by higher organic carbon contents in the bottom sediments, and occur during the odd-numbered, interglacial _ ${ }^{18} \mathrm{O}$ stages. The benthic Foraminifera indicate deposition in 120 to 250 metres water depth for the earlier part of the record, (c. $600 \mathrm{ka}$ to $c .200 \mathrm{ka}$ ), within the oxygen-minimum zone, with bottom water oxygen contents of $<0.5$ to $0.2 \mathrm{ml} / 1$, (inferred from the dominance of Bolivinellina humilis). Deposition in water depths approaching those of the present day, (c. 450 metres), is indicated from $c .160 \mathrm{ka}$ onwards, with better oxygenated bottom water conditions, probably corresponding to the lower part of the oxygen-minimum zone.
\end{abstract}

\section{INTRODUCTION}

ODP Leg 112 studied marine sediments of the Peru Continental Margin in relation to its tectonic evolution and its history of oceanic (coastal) upwelling. Hole 686B (Fig. 1) recovered a high sedimentation rate record of Pleistocene and earlier sediments (Suess \& von Huene, et al., 1988, 1990) from the margin of the Pisco Basin. The later part of this record was subject to a number of studies by a consortium of U.K. investigators (e.g. Farrimond et al., 1990; Lewis et al., 1990), in-

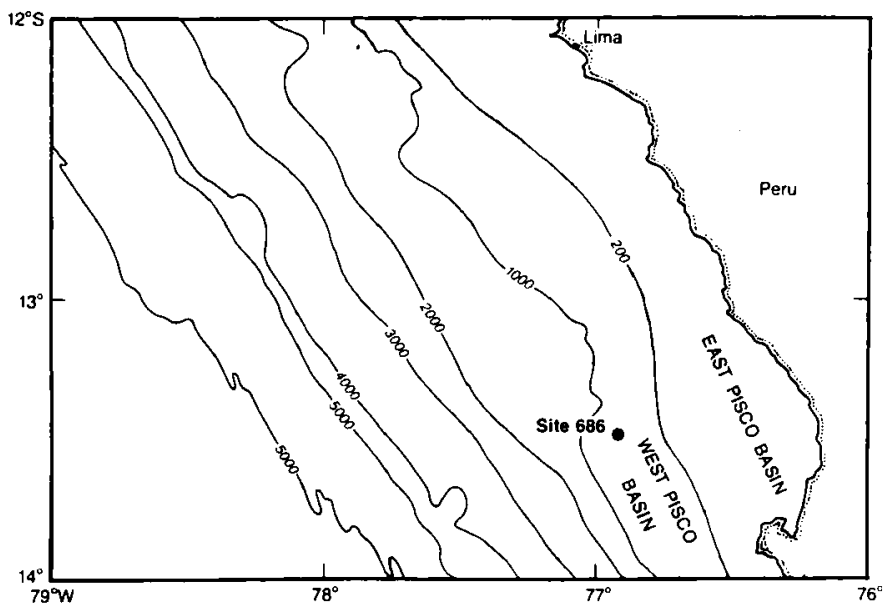

Fig. 1 Location of site studied in the Pacific Ocean, adjacent to the coast of Peru cluding the present authors. In this paper the results of an investigation of the benthic Foraminifera are reported, interpreted and compared with the results of other investigations of the top 105 metres of sediment, representing the mid and late Pleistocene (circa 600ka to $0 \mathrm{ka}$ ).

Hole $686 \mathrm{~B}$ was located on the western side of the Pisco Basin, at $13^{\circ} 28.81^{\prime} \mathrm{S}, 76^{\circ} 53.49^{\prime} \mathrm{W}$, in a water depth of 447 metres.

The somewhat sparse, and frequently thin-walled, benthic Foraminifera of Hole $686 \mathrm{~B}$ proved generally unsuitable for CdCa analysis (Jickells et al., 1990), and even, in the top 50 metres of the hole, insufficient for stable isotope analysis (Wefer et al., 1990). However, it is by no means the case that benthic Foraminifera are absent altogether from the upper 50 metres (cf. Wefer et al., 1990, p.359). Indeed, the variations in the benthic Foraminifera in that interval are of considerable interest.

\section{OVERALL RESULTS AND INTERPRETATION}

The quantitative results of extraction of all foraminifers ${ }^{\circ} 150$ $\mu \mathrm{m}$ from standard $10 \mathrm{ml}$ samples are presented in Fig. $2 \mathrm{~A}$ and Table 2. Fig. 2A shows that in 10 out of 29 samples (Table 1) no foraminifers were recovered at all. (These samples are not entered in Table 2.) The remaining samples contained up to 13 different species.

The most abundant species, and the dominant species in all samples from 50.41 to 101.39 metres below sea floor (mbsf), is 
CORE SECTION INTERVAL(cm) MBSF ${ }^{1}$ NO.SPECIES $\delta^{100}$ STAGE $^{2}$

\begin{tabular}{|c|c|c|c|c|c|}
\hline \multirow[t]{3}{*}{$01 \mathrm{H}$} & 02 & $64-66$ & 2.14 & 8 & 1 \\
\hline & 03 & $64-66$ & 3.64 & 11 & 1 \\
\hline & 05 & $64-66$ & 3.64 & - & 2 \\
\hline \multirow[t]{5}{*}{$02 \mathrm{H}$} & 01 & $40-43$ & 8.90 & - & 2 \\
\hline & 03 & $40-43$ & 11.90 & 6 & 4 \\
\hline & 04 & $40-43$ & 13.40 & 13 & 5 \\
\hline & 06 & $40-43$ & 16.40 & 10 & 5 \\
\hline & 07 & $40-43$ & 17.90 & - & 5 \\
\hline \multirow[t]{3}{*}{$03 \mathrm{H}$} & 02 & $56-58$ & 20.06 & - & 5 \\
\hline & 04 & $56-58$ & 23.06 & - & 5 \\
\hline & 06 & $56-58$ & 26.06 & 6 & 6 \\
\hline $04 \mathrm{H}$ & 01 & $14-17$ & 27.64 & - & 6 \\
\hline \multirow[t]{4}{*}{$05 \mathrm{H}$} & 01 & $59-61$ & 37.59 & - & 7 \\
\hline & 03 & $59-61$ & 40.59 & - & 7 \\
\hline & 05 & $59-61$ & 43.59 & 4 & 7 \\
\hline & 07 & $59-61$ & 46.59 & 6 & 7 \\
\hline \multirow[t]{2}{*}{$06 x$} & 01 & $91-95$ & 47.41 & - & 7 \\
\hline & 03 & $91-95$ & 50.41 & 1 & 7 \\
\hline 07X & 02 & $13-15$ & 57.41 & 6 & 8 \\
\hline $08 x$ & 02 & $110-114$ & 68.10 & 6 & 9 \\
\hline \multirow[t]{3}{*}{$09 x$} & 02 & $61-63$ & 75.89 & 4 & 10 \\
\hline & 06 & $61-63$ & 81.89 & 4 & 11 \\
\hline & 07 & $61-63$ & 83.89 & 7 & 11 \\
\hline \multirow[t]{3}{*}{$10 x$} & 02 & $18-22$ & 86.18 & 4 & 11 \\
\hline & 04 & $18-22$ & 89.18 & - & 11 \\
\hline & 05 & $18-22$ & 90.68 & 2 & 12 \\
\hline \multirow[t]{4}{*}{$11 x$} & 02 & $56-58$ & 95.39 & - & 12 \\
\hline & 05 & $56-58$ & 99.89 & 5 & 13 \\
\hline & 06 & $56-58$ & 101.39 & 8 & 14 \\
\hline & 07 & $56-58$ & 102.89 & - & 15 \\
\hline
\end{tabular}

1MBSF - metres below sea floor

${ }^{2}$ after Wefer et al., 1990

Table 1. Samples, from ODP Leg 112, Hole 686B, analyzed for Benthic Foraminifera
Bolivina seminuda humilis (Cushman and McCulloch), referred to as Bolivinellina humilis by Resig (1990) and herein, and as Bolivina seminuda s.l. by Oberhansli et al. (1990). This species characterises the oxygen-minimum zone at the present day, and is most abundant where bottom water oxygen concentrations fall to between $<0.5$ and $0.2 \mathrm{ml} / 1$ (Oberhansli et al., 1990). Off Peru it constitutes the major element of the upwelling assemblages, and comprises more than $50 \%$ of populations from the outer Outer Shelf (c.120 metres) into the upper Upper Bathyal (to $c .250$ metres), (Resig, 1990). Resig (1990) infers accumulation of the section from 60 to $100 \mathrm{mbsf}$ and below in Hole 686A in Upper Bathyal low-oxygen conditions, which compares well with our samples from 57.63 to $101.39 \mathrm{mbsf}$ in Hole 686B. From 46.59 to $2.14 \mathrm{mbsf}$, and particularly from 26.06 to 2.14 mbsf our samples from Hole 686B contain lower percentages of $B$. humilis accompanied by other species such as Brizalina interjuncta bicostata and Pseudoparrella subperuviana, which Resig (1990) considers as typical current-dominated assemblages, occurring at lower Upper Bathyal to upper Middle Bathyal depths (at around 450 metres water depth). She found similar assemblages in the upper $25 \mathrm{~m}$ of the section in Hole 686A (Resig, 1990).

Variations in foraminiferal assemblages in the Peruvian sediments recovered by ODP Leg 112 occur at all scales, ranging from the millimetric (Funnell and Malmgren, in preparation) to the kilometric. At the scale of sampling undertaken for the U.K. consortium studies on Hole 686B, (approximately 2.5 metre intervals) a systematic oscillation from nil up to 13 species of benthic Foraminifera occurs throughout the top 105 metres of the hole (Fig. 2A).

\section{COMPARISON WITH THE $\mathbf{U}^{\mathrm{K}}{ }_{37}$ INDEX}

The main interest of the benthic forminiferal variation (Funnell and Young 1989) is that it parallels two other parameters measured on Hole 686B by the U.K. consortium. The first of these is the $\mathrm{U}_{37}^{\mathrm{k}}$ Index of sea-surface temperature (Farrimond, et al., 1990; Fig. 2B). This index is based on the quantitative relationship between the di- (C37:2) and tri- (C37:3) unsaturated $\mathrm{C}_{37}$ alkenones obtained from marine sediments by gas chromatography. For details see Farrimond, et al. (1990) and papers referred to therein. The general equation is as follows:

$$
\mathrm{U}^{k}{ }_{37}=[\mathrm{C} 37: 2] /[\mathrm{C} 37: 2+\mathrm{C} 37: 3]
$$

(A more complex form of the index applies in cold conditions, where an additional tetra- (C37:4) unsaturated $\mathrm{C}_{37}$ alkenone is biosythesized.)

$\mathrm{Di}$ - and tri-unsaturated $\mathrm{C}_{37}$ alkenones are known to be biosynthesized by prymnesiophyte algae (coccolithophores) such as Emiliania huxleyi. An empirical relationship between the index and sea-surface temperatures was established by Eglinton et al. (1983) and confirmed, by culturing living algae. by Prahl and Wakeham (1987). As indicated in Fig. 2B the range in sea-surface temperatures inferred for the top 105 metres of Hole $686 \mathrm{~B}$ is from approximately $19^{\circ} \mathrm{C}$ to $27^{\circ} \mathrm{C}$. 
Warmer surface waters correspond very generally with the absence of benthic Foraminifera in the bottom sediments. Conversely cooler surface waters correspond with maximum numbers of species of benthic Foraminifera in the bottom sediments. The palaeoenvironmental indications of these benthic Foraminifera have been discussed above.

\section{COMPARISON WITH THE PERIDINACEAN/ GONYAULACACEAN (P/G) RATIO}

The second parameter investigated by the U.K. consortium in the top 105 metres of Hole 686B was the peridinacean (P)/ gonyaulacacean $(\mathrm{G})$ dinoflagellate cyst ratio, which is considered to be an index of upwelling intensity (Lewis et al., 1990; Wall et al., 1977). Most living peridinacean dinoflagellates are heterotrophic and feed mainly on diatoms, whereas gonyaulacacean dinoflagellates are photosynthetic. Therefore an association of the former with upwelling conditions supporting abundant diatom populations, and of the latter with more stratified water conditions, would be consistent with the inferred relationship between their relative abundances and the intensity of upwelling. In Hole 686B we find that the $\mathrm{P} / \mathrm{G}$ ratio (Fig. 2C) indicates generally low upwelling intensities at times when there are no benthic Foraminifera in the bottom sediments, and conversely high upwelling intensities when the benthic Foraminifera are well represented in the bottom sediments.

Therefore all three sets of U.K. consortium data are consist- ent in indicating periods of warmer surface waters, less upwelling, and no benthic Foraminifera alternating with periods of cooler surface waters, more upwelling and significant populations of benthic Foraminifera in the top 105 metres of Hole 686B (Fig. 2A,B,C).

\section{COMPARISON WITH ORGANIC CARBON CONTENT AND $\delta^{18}$ O STAGES}

A fourth parameter which shows a close relationship with the previous three, at least for the top 35 metres of Hole 686B, is the organic carbon content (Wefer et al., 1990; Fig. 2D). Warmer water, reduced upwelling, low or non-existent benthic foraminiferal assemblage episodes correspond with sediments containing relatively low organic carbon contents. Conversely cooler water, strong upwelling, good benthic foraminiferal assemblage episodes correspond with sediments of higher organic carbon content. This would be consistent with higher organic production, and preservation, during periods of stronger upwelling. The relationship falters however, below $35 \mathrm{mbsf}$. The correspondance between the U.K. consortium parameters (measured on sub-samples of the same samples) becomes less consistent (e.g. at $40 \mathrm{mbsf}$ ), and even where they are consistent (e.g between 60 and $80 \mathrm{mbsf}$ ) the organic carbon content takes on an erratic or even inverse relationship to that observed in the top 35 metres of the hole. In this interval relatively cool surface waters, stronger upwelling and diverse benthic foraminiferal

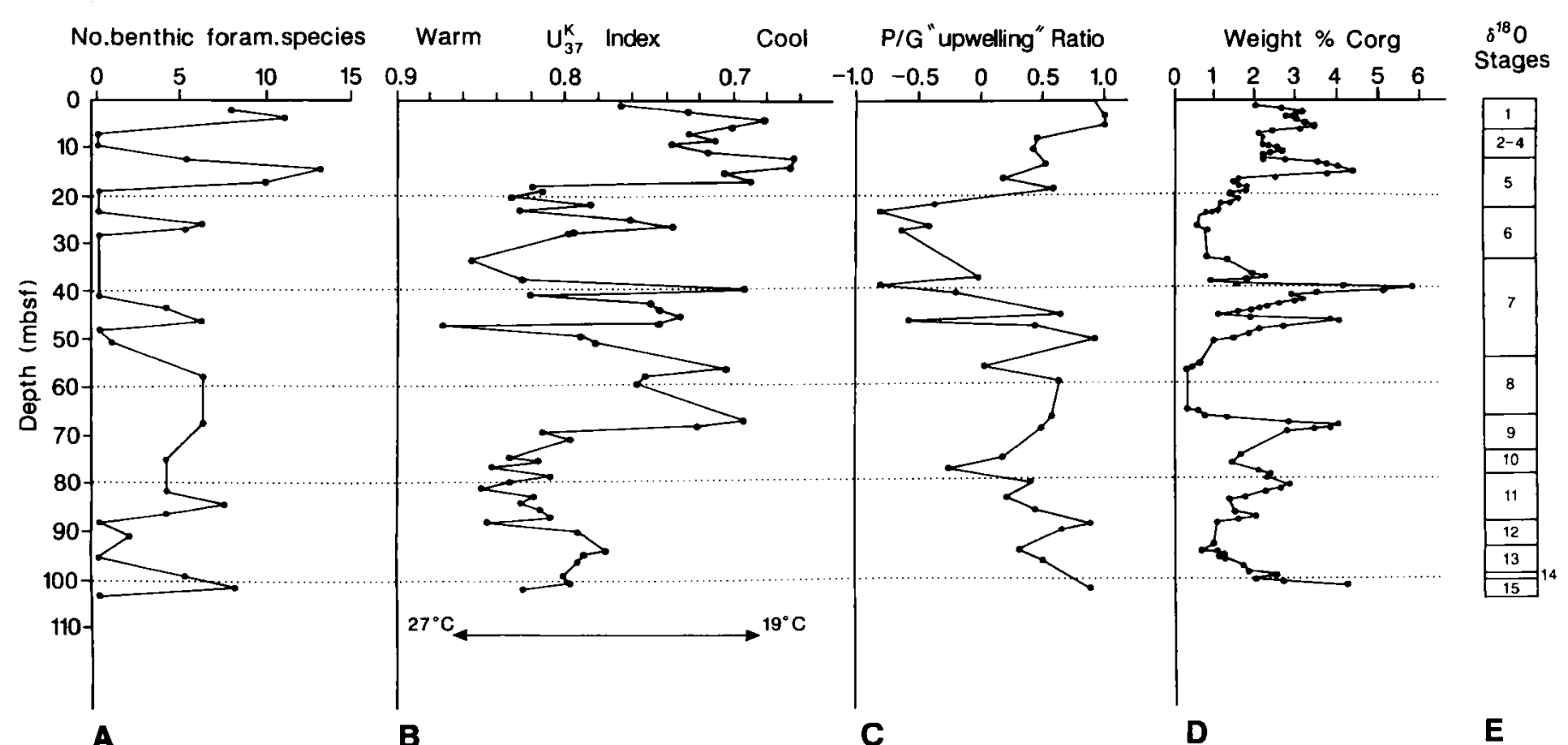

Fig. 2 Number of benthic Foraminifera species [A], compared with the $\mathrm{U}_{37}^{\mathrm{k}}$ "sea-surface water temperature" index [B], the peridiniacean/gonyaulacean $(\mathrm{P} / \mathrm{G})$ dinoflagellate cyst "upwelling" ratio; [C], the organic carbon weight $\%[D]$, and set against the provisional $\delta^{18} \mathrm{O}$ stage time scale $[\mathrm{E}]$ for the top 105 metres ( $c$. 6ooka to Oka) of ODP Hole 686B. 
assemblages appear to correpond with low carbon content bottom sediments. Whether this is due to very short time scale variability affecting the precision of inter-parameter comparisons, (when analyses have been made on different sample sets), or whether it is due to real differences in the relationships between the parameters is not clear at the present time. It should, however, be remembered that there is a systematic change over time in the depth facies of the sediments being observed, from outer Outer Shelf/upper Upper Bathyal ( $c .120$ to $250 \mathrm{~m}$ water depth) at $100 \mathrm{mbsf}$ to lower Upper Bathyal/ upper Middle Bathyal (c.450 m water depth) at the present day. More consistent relationships, between all four parameters, seem to apply in the period when sedimentation was proceeding in deeper water. The earlier period of less consistent relationships corresponds with a period of shallower water deposition, (at which depths the effects of glacio-eustatic sea-level change would have been relatively more important).

The chronology of Hole 686B has been difficult to establish. The paucity of benthic Foraminifera has prevented the establishment of a $\delta_{18} \mathrm{O}$ time scale from direct observations on Hole 686B materials above $50 \mathrm{mbsf}$ (Wefer et al., 1990). However, the close relationship between $\delta_{18} \mathrm{O}$ and organic carbon content in Hole 686B below $60 \mathrm{mbsf}$ has allowed a provisional overall allocation of the top 105 metres to $\delta_{18} \mathrm{O}$ stages, ranging from stage 15 at 102.5 to $106.3 \mathrm{mbsf}$ to stage 1 at the sediment surface (Wefer et al., 1990; Fig. 2E). Against this provisional time scale we can see that there is a tendency for maximum number of benthic Foraminifera species, minimum surface water temperatures, maximum upwelling and maximum organic carbon of sediments to characterise the interglacial, odd-numbered $\delta_{18} \mathrm{O}$ stages, with converse relationships characterising the glacial, even-numbered stages. However, the sample interval adopted for the U.K. consortium investigations is too wide to allow analysis of the precise relationship to likely Milankovitch periodicity insolation forcing.

\section{CONCLUSIONS}

1. Benthic Foraminifera from the mid to late Pleistocene (600ka to 0ka) of ODP Hole 686B from the margin of the Pisco Basin off Peru, show systematic variations in abundance and diversity that can be correlated with variations in other parameters observed in the same cores.

Few or no benthic Foraminifera occur at times of warmer surface water temperatures, lower intensities of upwelling, and lower organic carbon contents in bottom sediments. Generally speaking these periods correspond with the glacial $\delta_{18} \mathrm{O}$ stages. More diverse benthic foraminiferal assemblages, (up to 13 species), occur at times of cooler surface waters, higher intensities of upwelling, and higher organic carbon contents in bottom sediments. Generally speaking these periods correspond with interglacial $\delta_{18} \mathrm{O}$ stages.

2. The benthic Foraminifera, when present, indicate sediment accumulation at outer Outer Shelf/upper Upper Bathyal (c. 120 to $250 \mathrm{~m}$ ) water depths, from $105 \mathrm{mbsf},(c .600 \mathrm{ka}), \delta_{18} \mathrm{O}$ stage 15 to about $45 \mathrm{mbsf},($ c. $200 \mathrm{ka}), \delta_{18} \mathrm{O}$ stage 7 , under low oxygen bottom water conditions $(<0.5$ to $0.2 \mathrm{ml} / \mathrm{l})$. Accumulation at lower Upper Bathyal/upper Middle Bathyal (c. $450 \mathrm{~m}$ ) water depths is indicated from about $30 \mathrm{mbsf},(c .160 \mathrm{ka}), \delta_{18} \mathrm{O}$ stage 6 up to the present day, under current-influenced bottom conditions below the main development of the oxygen-minimum zone.

3. An interesting feature of the benthic forminiferal record at ODP Site 686 is the increase in abundance and diversity during times of higher surface water productivity, (inferred from the dinoflagellate cyst "upwelling" index, and supported by the $\mathrm{U}_{\mathrm{k} 37}$ "surface water temperature" index). This occurs in spite of the inferred low oxygen content of the bottom waters, and the sometimes high organic carbon content of the bottom sediments, at such times. A similar increase in abundance and diversity of benthic Forminifera has been found during times of higher surface water divergence and productivity, in late Pliocene and early Pleistocene sediments, from the equatorial Indian Ocean at ODP Site 709 (Andrews et al., 1990).

Explanation of Plate 1.

Scale Bars $=50 \mu \mathrm{m}$

Fig. 1. Bolivinellina humilis (Cushman and McCulloch)

Fig. 2. Pseudoparrella subperuviana (Cushman)

Fig. 3. Cancris inflatus (d'Orbigny)

Fig.4. Brizalina interjuncta bicostata (Cushman)

Fig. 5. Uvigerina peregrina Cushman

Fig. 6. Suggrunda eckisi Natland

Fig. 7. Buliminella subfusiformis Natland

Fig. 8. Brizalina pseudobeyrichi (Cushman)

Fig. 9. Brizalina spissa (Cushman)

Fig. 10. Fontbotia wuellerstorfi (Schwager)

Fig. 11. Hanzawaia concentrica Smith

Fig. 12. Nonionella miocenica Cushman 


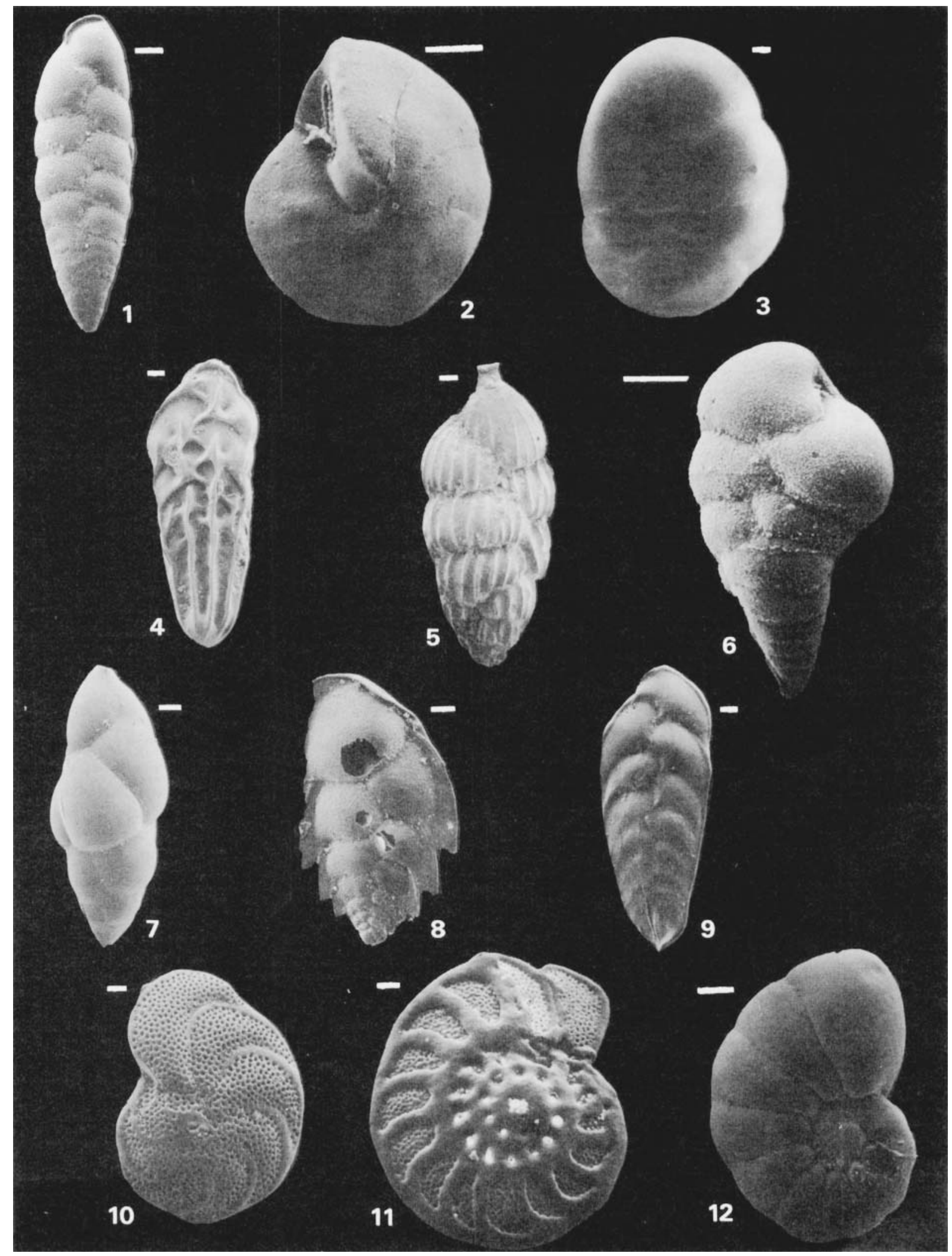


Benthic Foraminifera

Metres below sea floor

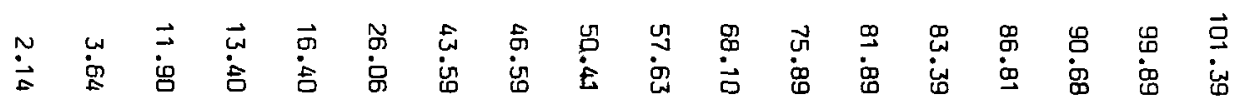

Number of species

Bolivinellina humilis

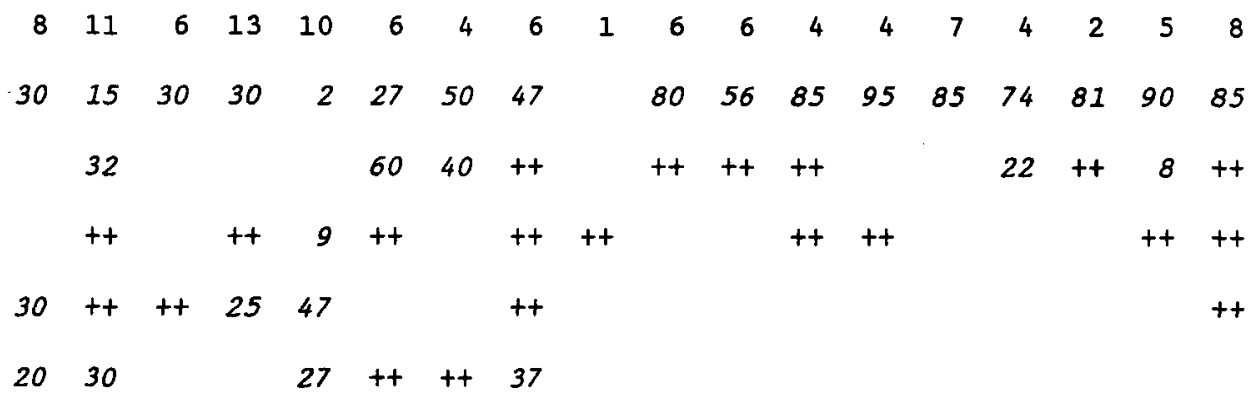

Pseudoparrella subperuviana

Cancris inflatus

Cassidulina laevigata

Brizalina interjuncta costata

Gyroidine nitidula

$++\quad++30$ t+ ++

Cassidulina cushmeni

$30++$

Uvigerina peregrina

7

Suggrunda eckisi

$++\quad 22$

$++$

Only the more abundant species are entered as percentages.

other species: Bolivina affinis, B. costata, Buliminella elegantissima, B. elongata,

B. striatula, B. subfusiformis, Brizalina pseudobeyrichi, B. spissa, Cancris carmensis,

Cancris Iimbata, Cassidulina subglobosa, Fontbotia wuellerstorfi, Globobulimina auriculata,

G. pacifica, Hanzawaia concentrica, Nonionella miocenica, Virgulinella sp.

Table 2. Distribution of benthic Foraminifera in ODP Hole 686B to 101.39 metres below sea floor (mbsf)

\section{ACKNOWLEDGEMENTS}

The research on which this paper is based was supported by NERC ODP Special Topic Research Grant GST/02/251 and formed part of the U.K. consortium research on ODP Leg 112.

\section{Manuscript received November 1989 \\ Revised manuscript accepted August 1990.}

\section{REFERENCES}

Andrews, J. E., Funnell, B. M., Jickells, T. J., Shackleton, N. J., Swallow, J.E., Williams, A.C. and Young, K. A., 1990, Preliminary assessement of cyclic variations in foraminifers, barite, and cadmium/ calcium ratios in early Pleistocene sediments from Hole $709 \mathrm{C}$ (equatorial Indian Ocean). Proc. ODP, Sci. Results, 115, 611-619.

Eglinton, G., Brassell, S. C., Howell, V., and Maxwell, J. R., 1983, The role of organic geochemistry in the Deep Sea Drilling Project (DSDP/IPOD). In Bjoroy, M. et al. (Eds.), Advances in Organic Geochemistry 1981: Chichester (Wiley), 391-400.

Farrimond, P., Poynter, J. G., and Eglinton, G., 1990, A molecular stratigraphic study of Peru Margin sediments, Hole 686B, Leg 112. Proc. ODP. Sci. Results, 112, 547-553.

Funnell, B. M. and Malmgren, K. A., (in preparation), Microdistribution of benthic Foraminifera in late Pleistocene upwelling sediments, off Peru, ODP Leg 112.
Funnell, B. M. and Young, K. A., 1989, Correlation between sea surface temperature $\left(U_{k: 7}\right)$ and bottom water anoxia (benthic foraminiferal diversity) during the late Quaternary of ODP Site 686B, off Peru. TERRA abstracts, 1 (Third International Conference on Palaeo-Oceanography), 65.

Jickells, T. D., Funnell, B. M., and Young, K. A., 1990, Cadmium/ calcium ratios in benthic foraminifers recovered during Leg 112. Proc. ODP Sci. Results, 112, 407-409.

Lewis, J., Dodge, J. D., and Powell, A. J., 1990, Quaternary Dinoflagellate Cysts from the upwelling system offshore Peru, Hole 686B, ODP Leg 112. Proc. ODP Sci. Results, 112, 323-328.

Oberhansli, H., Heinze, P., Diester-Haass, L., and Wefer, G., 1990, Upwelling off Peru during the last $430,000 \mathrm{yr}$ and its relationship to the bottom-water environment, as deduced from coarse grain-size distributions and analyses of benthic foraminifers at Holes 679D. 680B and 681B, Leg 112. Proc. ODP Sci. Results, 112, 369-390.

Prahl, F. G., and Wakeham, S. G., 1987, Calibration of unsaturation patterns in long-chain ketone compositions for palaeotemperature assessment. Nature, 330, 367-369.

Resig, J. M., 1990, Benthic foraminiferal stratigraphy and paleoenvironments off Peru, Leg 112. Proc. ODP. Sci. Results, 112, 263-296.

Wefer, G., Heinze, P., and Suess, E., 1990. Stratigraphy and sedimentation rates from oxygen isotope composition, organic carbon content, and grain-size distribution at the Peru upwelling region: Holes 680B and 686B. Proc. ODP. Sci. Results, 112, 355-367. 